\title{
A note on enzyme activity in the serum of Hucul horses of various ages
}

\author{
Maria Kulisa ${ }^{1}$ and M. Ormian ${ }^{2}$ \\ ${ }^{1}$ Department of Horse Breeding, ${ }^{2}$ Department of Cattle Breeding, \\ Kraków Agricultural University \\ Al. Mickiewicza 24/28,30-059 Kraków, Poland
}

(Received 10 February 1997; accepted 15 May 1997)

\begin{abstract}
The activity of ceruloplasmin (Cp), alkaline phosphatase (AP), acid phosphatase (AcP) and amylase (Am) in the serum of Hucul mares and stallions divided into age groups (weanlings, yearlings, 2-years-old and adults) was estimated during the winter feeding season.

Statistically significant and highly significant differences were found in the activity of enzymes between age groups of stallions and mares. Activity lcvels of $\mathrm{Cp}, \mathrm{AP}$ and $\mathrm{AcP}$ in individual age groups were mostly higher in the serum of mares than in stallions, except for Am. The AP activity decreased with age, from 5.62 to $2.94 \mathrm{IU} / 1$ in mares and from 4.78 to $2.99 \mathrm{IU} / 1$ in stallions.
\end{abstract}

KEY WORDS: Hucul horses, enzyme activity, age

\section{INTRODUCTION}

Hucul horses are a mountain breed known early as the 18 th century. The name derived from the region of the eastern Carpathian Mts. from which they originate. The severe mountain climate made them resistant to adverse environmental conditions and contributed to their iron constitution. Hucul horses are noted for being docile, clever and willing. They are characterized by high fertility and are excellent pack-and draught-horses. Trot is their favourite pace and they display an inborn ability to jump over obstacles. Interest in raising this breed in Poland has been increasing for several years. At present about 215 Hucul mares are being bred, including 69 kept at the Stud Gladyszów. 
The enzymes in the blood serum are largely metabolically inactive, since there are no substrates in the serum to be acted upon. The activity level of those enzymes is determined by a number of factors such as health, age, breed, sex and specific traits (Sergienko et al., 1974; Makavyeev et al., 1976; Sato et al., 1978; Gill et al., 1979; S7warocka-Priebe and Gill, 1984; Kulisa 1991; Thoren-Tolling, 1988). Many other blood indices also undergo some changes over time (Krumrych and Wiśniewski 1994).

The activity of many enzymes stabilizes with age and, according to Richterich (1958), is equivalent to a defined level of their production. In a number of earlier studies it was found that the activity of certain enzymes contained in the blood cells are hereditary in nature (Mc Cosker, 1961; Gahne, 1970; Kelly et al., 1971; Lie, 1980).

The aim of this study was to determine the activity levels of ceruloplasmin (Cp), alkaline phosphatase (AP), acid phosphatase (AcP) and amylase (Am) in the seraum of Hucul mares and stallions divided into the following age groups: weanlings, yearlings, 2-years-old and adults.

\section{MATERIAL AND METHODS}

Studies were carried out on 123 Hucul horses of various age, from the Stud Siary, that were divided according to sex and age into the following groups: adult horses (over 3 years), 2-years-old, yearlings and weanlings. Basic feeds given to horses were meadow hay, oat grain and red carrots.

Blood samples were collected from the jugular vein once into test tubes, without anticoagulant, on the same day from all horses, during in the winter feeding season. The enzyme activity was determined in the centrifuged fresh blood serum. The $\mathrm{Cp}$ activity was estimated by a colorimetric method according to Houchin (1958) and those of alkaline phosphatase (AP) and acid phosphatase (AcP) - by the colorimetric method described by Linhardt and Walter (1970), while the amylase (Am) activity by the colorimetric method according to Street (Linhardt and Walter, 1970).

Statistical analysis of mean values, standard deviations and coefficients of variation were done in individual groups and mean values were compared using Duncan's test (Ruszczyc, 1970).

\section{RESULTS AND DISCUSSION}

The activity levels of the studied enzymes in the blood sera of mares, according to age groups, are presented in Table 1. The ceruloplasmin activities in weanling 
TABLE 1

The activity of some selected enzymes in the blood sera of IIucul mares according to age groups

\begin{tabular}{|c|c|c|c|c|c|c|}
\hline \multirow{3}{*}{ Age group } & \multirow{3}{*}{$\mathrm{n}$} & & \multicolumn{4}{|c|}{ Enzyme activity } \\
\hline & & & $\mathrm{Cp}$ & AP & $\mathrm{AcP}$ & Am \\
\hline & & & $\mathrm{mg} / 1$ & $\mathrm{U} / 1$ & $\mathrm{U} / 1$ & $\mathrm{U} / \mathrm{I}$ \\
\hline \multirow{3}{*}{$\Lambda$ bove 3 years } & \multirow{3}{*}{49} & Mean & $32.40^{a}$ & $2.94^{\mathrm{Aa}}$ & $0.41^{2}$ & 10.85 \\
\hline & & SD & 6.68 & 0.75 & 0.15 & 5.38 \\
\hline & & $\mathrm{CV}$ & 20.62 & 25.44 & 35.59 & 49.65 \\
\hline \multirow{3}{*}{2 years } & \multirow{3}{*}{8} & Mean & $37.39^{\mathrm{b}}$ & $3.48^{\wedge}$ & $0.54^{b}$ & 7.17 \\
\hline & & SD & 10.57 & 0.58 & 0.08 & 5.27 \\
\hline & & $\mathrm{CV}$ & 28.28 & 16.55 & 14.30 & 73.49 \\
\hline \multirow{3}{*}{1 year } & \multirow{3}{*}{12} & Mean & $37.22^{b}$ & $4.72^{b}$ & $0.56^{\mathrm{b}}$ & 8.02 \\
\hline & & SD & 8.19 & 0.82 & 0.09 & 3.80 \\
\hline & & $\mathrm{CV}$ & 22.00 & 17.46 & 16.64 & 47.34 \\
\hline \multirow{3}{*}{ Weanling fillies } & \multirow{3}{*}{13} & Mean & $37.01^{\mathrm{b}}$ & $5.62^{8}$ & $0.59^{b}$ & 8.24 \\
\hline & & SD & 4.08 & 1.05 & 0.11 & 3.89 \\
\hline & & $\mathrm{CV}$ & 11.02 & 18.68 & 18.53 & 47.27 \\
\hline
\end{tabular}

$a, b-P \leqslant 0.05$

A, $\mathbf{B}-\mathbf{P}<0.01$

fillies, yearlings and 2-years-old displayed very close values. However, adult mares showed slightly lower $\mathrm{Cp}$ activities, and the differences were significant.

The levels of alkaline phosphatase activity attained the highest values in weanling fillies, i.e., in the youngest horses. A gradual decrease in AP activity was observed with age, reaching the lowest values in mares over 3 years old.

Highly significant differences in AP activity were found between weanling fillies and 2-years-old as well as mares over 3 years of age, while significant differences appeared between yearlings and the oldest mares. The activity pattern of acid phosphatase was similar, attaining the highest levels in the blood sera of weanling fillies and the lowest in mares over 3 years of age. Statistically significant differences in the levels of AcP activity were found between mares over 3 years and the remaining age groups of mares. The level of amylase activity beginning with weanling fillies was found to decrease with age, attaining the lowest value in 2-years-old. However, the highest activity of Am was found in mares over 3 years old, although the differences were not statistically significant.

The activity of the studied enzymes in the blood scra of stallions is presented in Table 2. The highest $\mathrm{Cp}$ activity was found in the group of weanling foals, whereas in the remaining groups of stallions $\mathrm{Cp}$ activity was about the same. Statistically highly significant differences in $\mathrm{Cp}$ activity were found between weanling foals and the rest of the stallion age groups. 
TABLE 2

The activity of some sclected enzymes in the blood sera of Hucul stallions according to age groups

\begin{tabular}{|c|c|c|c|c|c|c|}
\hline \multirow{3}{*}{ Age group } & \multirow{3}{*}{$\mathrm{n}$} & & \multicolumn{4}{|c|}{ Enzyme activity } \\
\hline & & & $\mathrm{Cp}$ & AP & $\mathrm{AcP}$ & Am \\
\hline & & & $\mathrm{mg} / 1$ & $\mathrm{U}_{/} / 1$ & $\mathrm{U} / 1$ & $\mathrm{U} / \mathrm{l}$ \\
\hline \multirow{3}{*}{ Above 3 years } & \multirow{3}{*}{6} & Mean & $30.85^{\mathrm{B}}$ & $2.99^{a}$ & 0.35 & $18.52^{\mathrm{a}}$ \\
\hline & & SD & 3.42 & 0.41 & 0.11 & 5.32 \\
\hline & & $\mathrm{CV}$ & 10.09 & 13.79 & 32.07 & 28.74 \\
\hline \multirow{3}{*}{2 years } & \multirow{3}{*}{6} & Mean & $30.24^{\mathrm{B}}$ & 3.01 & 0.36 & $10.02^{\mathrm{b}}$ \\
\hline & & SD & 4.86 & 0.66 & 0.09 & 4.71 \\
\hline & & $\mathrm{CV}$ & 16.09 & 22.01 & 26.28 & 46.99 \\
\hline \multirow{3}{*}{1 year } & \multirow{3}{*}{15} & Mean & $30.14^{\mathrm{B}}$ & 3.86 & 0.38 & $10.98^{b}$ \\
\hline & & SD & 6.55 & 0.99 & 0.07 & 10.01 \\
\hline & & $\mathrm{CV}$ & 21.75 & 25.77 & 19.16 & 91.14 \\
\hline \multirow{3}{*}{ Weanling fillies } & \multirow{3}{*}{14} & Mean & $38.61^{\mathrm{A}}$ & $4.78^{\mathrm{b}}$ & 0.37 & 13.95 \\
\hline & & SD & 5.77 & 1.66 & 0.09 & 6.76 \\
\hline & & $\mathrm{CV}$ & 14.95 & 34.65 & 24.99 & 48.49 \\
\hline
\end{tabular}

a, b $-P \leqslant 0.05$

$\Lambda, B-P \leqslant 0.01$

The highest AP activity was in the sera of weanling foals $(4.78 \mathrm{U} / \mathrm{l})$ and decreased with the age of stallions. The lowest AP activity (2.99 U/l) was found in stallions over 3 years of age. Significant differences were only found between weanling foals and stallions over 3 years old. AcP activity in the serum of stallions was found to decrease as the stallions aged, however, the differences between groups proved to be statistically non significant.

The level of Am activity in weanling foals was higher than in yearlings or 2 -years-old stallions, reaching the highest values in adult individuals. Significant differences were found only between adult stallions and 1 or 2-years-old stallions (Table 2).

While analysing the activity of the studied enzymes in the blood sera of Hucul horses it could be observed that the highest levels occurred in the youngest foals (weanlings). However, they decreaseding with age. The activity of $\mathrm{Cp}, \mathrm{AP}$ and AcP in particular age groups was usually higher in mares except for amylase.

Highly significant differences in $\mathrm{Cp}$ activity levels were found between mares and stallions in the groups of yearlings and 2-years-old, while differences in AP activity between mares and stallions were highly significant in the groups of weanlings and yearlings, and significant in 2-years-old.

Highly significant differences were found in AcP activity levels between sexes in the groups of weanlings, yearlings and 2-years-old. 
Total phosphatase activity (AP + AcP) was about $15 \%$ higher in stallions ( age group above 3-years-old) compared to mares of the same age. In the remaining age groups total phosphatase activity was lower by $16-20 \%$ in stallions. Also, highly significant differences between sexes were found in the groups of animals above 3 years of age, and significant differences were in the group of weanlings. Mares and stallions above 3-years of age displayed very similar activity levels of the studicd enzymes, with the exception of Am.

Kombiegov et al. (1978) did not find any ceruloplasmin activity in the blood of pure-bred Arabian foals aborted at 7-10 months. In another study, Kombiegov et al. (1983) determined the ceruloplasmin level in the serum of foals at birth, and after $3,4,5$ and $24 \mathrm{~h}$ as well as at 2, 3 and 5 months of age. Those studies did not reveal the presence (activity) of ceruloplasmin up to $5 \mathrm{~h}$ after birth. At $24 \mathrm{~h}$ after birth the ceruloplasmin level was estimated at $1.00 \mathrm{mg} \%$ with a subsequent increase, attaining a value of $12.6 \mathrm{mg} \%$ at two months of age.

The AP activity level according to Sato et al. (1978) was clearly dependent on the horse's age. The highest AP activity was shown by new-born foals, then a marked decrease in the mean activity of that enzyme up to an age of six months was observed (Sato et al., 1979). Beginning at 6-8 months of age the serum AP activity in foals is found to decrease much more slowly, attaining a comparatively stable level at the age of about 2 years (Thoren-Tolling, 1988). The observed decrease in AP activity with aging may be related to osteogenesis (Sato et al., 1975; Thoren-Tolling, 1988).

However, no studies were found which traced the broad spectrum of AcP activity with respect to horse's age. Differences in phosphatase levels occurring between age groups of stallions and mares may by indicative of various metabolic profiles, slower ossification and its later termination in stallions. Relatively few papers are reported in literature on amylase activity in the serum of horses. This may result from the lack of a specific method of measuring it (Szczeklik, 1974).

Changes in enzymatic activity levels related to horse's age are undoubtedly an outcome of the modifications occurring in the metabolic profile during a horse's life. It can be assumed that the differential metabolic profile is dependent on the type of horse utility.

\section{CONCLUSIONS}

Enzyme activity changes between groups of horses in different ages were similar in mares and stallions. Ceruloplasmin and basic or acid phosphatase activities in blood sera of resting groups of different ages were higher in mares whereas amylase activity was higher in stallions. 


\section{REFERENCES}

Gahne B., Bengsson S.. Sandberg K.. 1970. Genctic control of cholinesterase activity in horse serum. Anim. Blood Groups Biochem. Genet. 1, 207-212

Gill J., Szwarocka-Priebe T., Krupska U., Perłowska A, .1979. Seasonal changes in hematological indices of protein and glycoprotein levels and activity of some enzymes in Arabian horses. Bull. Acid. Pol. Sci., Scr. Biol. 26, 715-719

Houchin O.B., 1958. A rapid colorimetric method for the quantitative detcrmination of copper oxidase activity (Ceruloplasmin). Clin. Chem. 4, 519-523

Kambiegov B.D., 1978. Polimorfnyie sistemy bielkov syvorotki krovi loshadej w ontogeneze. Izv. Timirjaz. Sel'skhoz. Akad.1, 219-221

Kambiegov B.D., Lukash N.S., Jezavkina W.J., Jasaian A.M., 1983. Dinamika sodierzhania, ceruloplasmine v krovi zhrebiat. Izv. Timirjaz. Sel'skhoz. Akad. 1, 192-193

Kelly E.P., Stormont C., Suzuki Y., 1971 . Catalase - a new polymorphism in horses and cattle. Anim. Blood Groups Biochem. Genet. 3, suppl. 1, 46

Krumych W., Wiśniewski E., 1994. Effect of age on certain biochemical blood indicators in the Polish primitive horse (Konik) (in Polish). Prace Mat. Zoot. 46, 83-87

Kulisa M., 1991. The albumin and transferrin polymorphism and activity of some enzymes in blood serum of the pure-blood Arabian mares (in Polish). Zesz. Nauk AR Kraków, No 160, Thesis

Lie O, 1980. Genetic variation in the serum lysozyme activity in cattle. Acta Vet. Scand. 21, 448-450

Linhardt K., Walter K., 1970. Methods of Enzymatic Analysis. Acad. Press. New York, London

Makvyeev T.S.C., Iarov I., Kisov M., 1976. The activity of some blood serum enzymes in English Thoroughbred horsees (in Bulgarian). Żiv. Nauki. 13 (3) , 44-50

Mc Cosker P.J., 1961. Paraphenylenediamine oxidase activity and copper levels in mammatian plasmas. Nature.190, 887-889

Richterich R., 1958. Enzymathologie. Springer-Verlag, Basel

Ruszczyc Z., 1978. Methodology of Zootechnical Experiments (in Polish). PWRiL, Warszawa

Sato T., Oda K., Kubo M., 1978. Hematological and biochemical values of Thoroughbred foals in the first six months of life. The Cornell Vet. 69, 3-19

Sergienko G.F., Sergienko S.S., 1974. Dinamika niekotorykh biochimikheskich pokazatelej krovi ryssakov v zavisimosti ot intensyvnosti trenirovki. Dokl. Timirjaz. Sel'skhoz. Akad. 200, 89-94

Szczeklik E., 1974, Chemical Enzymology (in Polish). PZWL, Warszawa

Szwarocka-Priebe T., Gill J., 1984. Seasonal enzyme activity changes in two aminotransferases, AsPAT and AlAT, acid and alkaline phosphatase and aldolase in the serum of Thoroughbred horses during a racing season. Acta physiol. pol. 3, 249-256

Thoren-Tolling K., (1988). Serum allkaline phosphatase isoenzymes in the horse - Variation with age, training and in different pathological conditions. J. Vet. Med. 35, 13-23

\section{STRESZCZENIE}

\section{Aktywność enzymów w surowicy koni huculskich w różnym wieku}

Aktywność ceruloplazminy (Cp) oraz zasadowej (AP) i kwaśnej fosfatazy (AcP) w surowicy krwi klaczy oraz ceruloplazminy (Cp), zasadowej fosfatazy (AP) oraz amylazy (Am) we krwi klaczy oraz ogierów, oznaczona $w$ okresie żywienia zimowego, różniła się istotnie w zależności od wieku (odsadki, ročniaki, dwuletnie i stars e). Aktywność $\mathrm{Cp}$, Ap i AcP w surowicy krwi koni w poszczególnych grupach wiekowych była wyższa u klaczy niż u ogierów, aktywność Am wyższa u ogierów niż klaczy. Aktywność AP obniżała się wraz z wiekiem, z 5,62 do 2,92 U/1 u klaczy oraz z 4,78 do $2,99 \mathrm{U} / 1$ u ogierów. 